University of Nebraska - Lincoln

DigitalCommons@University of Nebraska - Lincoln

Library Philosophy and Practice (e-journal)

Libraries at University of Nebraska-Lincoln

November 2020

\title{
Undergraduates' Perception of Library Service Quality and Value in the 21st-Century in Southeast Nigeria: A Case Study
}

Obiora Kingsley Udem

Department of Library and Information Science, Nnamdi Azikiwe University, Awka, ok.udem@unizik.edu.ng

Joy Iguehi Ikenwe

Department of Library and Information Science, Ambrose Alli University, Ekpoma, iguehi.ikenwe@aau.ekpoma.edu.ng

Ethel Chinenye Ugwuamoke

Department of Library and Information Science, Nnamdi Azikiwe University, Awka, delumen61@gmail.com

Follow this and additional works at: https://digitalcommons.unl.edu/libphilprac

Part of the Scholarly Communication Commons

Udem, Obiora Kingsley; Ikenwe, Joy Iguehi; and Ugwuamoke, Ethel Chinenye, "Undergraduates' Perception of Library Service Quality and Value in the 21st-Century in Southeast Nigeria: A Case Study" (2020).

Library Philosophy and Practice (e-journal). 4501.

https://digitalcommons.unl.edu/libphilprac/4501 


\title{
Undergraduates' Perception of Library Service Quality and Value in the 21 ${ }^{\text {st-Century in }}$ Southeast Nigeria: A Case Study
}

\begin{abstract}
The purpose of this study is to explore the undergraduates' perception of the quality and value of library services offered to them in the $21^{\text {st }}$-century in federal universities in Southeast Nigeria. Prof. Festus Aghagbo Nwako Library (PFANL) in Nnamdi Azikiwe University Awka was used as a case study. A descriptive survey research design was adopted for the study. From a population of 14,196 registered regular undergraduates' users of the library, a sample of 120 was selected through an accidental sampling technique. From 120 questionnaires distributed, 103 copies received were valid, 17 responses were either incomplete or not answered, and so, the efficient rate was 85.8 percent. The study employed the use of two instruments which include: observation checklist, used to ascertain the available library services, and a questionnaire used to elicit users' perception of library service quality and value. The instruments were face validated by two experts in Nnamdi Azikiwe University Awka. The internal consistency of the instrument on library services used by the undergraduates was established using Kudder-Richardson which yielded 0.86 while Cronbach's alpha coefficient was used for the undergraduates' perception of quality and value of library services offered to them which yielded 0.78 and 0.81 respectively. Frequency count, percentage, mean and standard deviation using SPSS, were used to analyze data from research questions, t-test was used to test hypotheses. The major findings revealed that the undergraduates have a positive perception of the quality of library services offered to them at Prof. Festus Aghagbo Nwako Library (PFANL). However, they had a negative perception of the quality of computer/Internet services and reprographic services offered to them. This shows that these two services should immensely be improved upon in this $21^{\text {st }}$-century. The study equally shows that undergraduates have high value for library services offered to them. Nevertheless, they have low value on computer/internet services and reprographic services which are most needed in this $21^{\text {st }}$-century. The finding also revealed the host of impediments that affects high perception of library services quality and value in this 21 st century at PFANL to include; insufficient current information resources, an unfriendly attitude of staff, slow internet connectivity, limited access, insufficient availability of modern facilities, insufficient training on technology use and unsteady power supply. The finding further revealed that there is no significant difference in mean rating of male and female perception of quality and value of library service offered to them at PFANL. Based on the findings, it was recommended among others that the library management at PFANL should sustain undergraduates' level of perceived library quality and value, and boost it by providing continuously, relevant and current information resources and services especially on the aspect of computer/Internet services and reprographic services suitable in this $21^{\text {st }}$-century.
\end{abstract}

Keywords: $21^{\text {st }}$-century, University libraries, Undergraduates, Library services, Perception, Quality Service, Value of library Service, Southeast Nigeria, Prof. Festus Aghagbo Nwako Library. 


\section{Introduction}

The essential role $21^{\text {st }}$-century academic library plays, specifically university libraries to hold up research, teaching, and learning in the higher institutions cannot be overlooked. To realize this, university libraries provide modern infrastructure, information resources, and services to enhance students' academic activities and pursuit in this technology age. Online Computer Library Centre (OCLC) (2011) expressed that libraries in universities are currently offering new services to their users, responding to the technology landscape. Gama (2013) asserted that "university library users are generally scholars and students whose use of library services assists them for their academic work". This is simply hinged on the fact that the $21^{\text {st }}$-century university library plays a crucial role in promoting knowledge which has necessitated the advancement of these academic activities through the availability and provision of library services to its users. A cursory look at this indicates that users are the basic reason the library exists and the library is service-oriented, as it has the sole responsibility of providing the best quality services to achieve successfully, their objectives, and meet their users' high expectations. Thus, without these users, the library is not complete as it becomes a market filled with goods and no patronage. According to Nyantakyi (2016, p. 25), "If the service provided in university libraries meets users' information needs or expectations, it can be considered that there is quality service when the information meets users' needs and expectations and used by them".

Kiriri (2018) suggested that libraries as service providers need to anticipate the needs of their users and demonstrate results to present library users, for continuity as reliable service providers. This implies that it is expedient for university libraries to provide quality services appreciable by users. In this regard, quality service (QS) is the standard of library services as measured against users' needs or expectations. Library Service Quality (LSQ), in its presentday concept, is users' comparison of perceived expectations (PE) of library services versus perceived services. Fagan in Moses et al (2016, p. 14) defined service quality as the "experience assessment carried out by the users' on how good/bad or pleasant/unpleasant the service is". Kiriri (2018) defined service quality as "the difference between the actual customer expectations of services and the perceived services". If the services offered by libraries, especially university libraries are of good quality, there is surely no doubt, that the library users' will place value on them. That is, they are bound to attach more value to the library services. Nyantakyi-Baah (2016) opined that university libraries must exhibit their value to the activities of their parent body, in order not to become trivial or peripheral.

Users' value of library services is users' judgment in regards to the importance, usefulness, or worth of library services offered to them. It is paramount to note that, the value of the services of libraries to undergraduates' overtime has become an important factor in higher institutions most especially universities, which has forced librarians to think out of the box on how library services can be of great benefit to users and enhance their academic prowess. This is due to the fact that information users in this $21^{\text {st }}$-century know what they want and the library services that are more useful to them. This makes the users' of the $21^{\text {st }}$-century, who are stakeholders, in the best stance to judge these services by expressing their opinion or perception about the library service quality and value, since they are the rightful consumers of the services. This shows that it is unarguably adjudged that quality service is a competitive 
weapon and priority for libraries that should provide valuable services to their users' as the quality is the foundation of valuable services.

Notably, perception of library service quality is the degree library users see their expectations and information needs being met through the services their libraries provide. In other words, the gap between library users' expectations and the actual services provided is reduced to the nearest minimal. That is, if the expectations of the library users are greater than the actual services provided, then the users' perception of the quality and value of the library services will be low which will lead to dissatisfaction with the services. Likewise, the higher their expectations are met, the more satisfied they are with the services. This shows that the satisfaction of the user is an indicator of quality and valuable services offered. This is confirmed in the study of Moses (2016) that library service quality has a direct significant positive effect on the value of library services, library usage, and user satisfaction. In a nutshell, user satisfaction is the willingness of users' to patronize or visits the library again to use their services. In this vein, Ahmad and Islam (2012, p. 20) asserted that "libraries need to improve their service quality to achieve high students' satisfaction with the library services".

Assessment of university library services quality as pointed by Adamu (2017) should be considered as a management tool, purposely applied to determine how the library is serving the needs and expectations of its users effectively and efficiently. Obviously, library service quality and value is a modern tool librarian or library management use to understand users' opinion about the services provided to them and act on it. Basically, these tools help libraries to improve on their services and offering better quality services, that are valuable to users', especially in the $21^{\text {st }}$-century. According to Becker, Hartle, and Mhlauli (2017, p. 14), "feedback on the levels of service provided is essential for future planning of library services, allocation of staff and identification of areas for improvement". "By developing users' focused feedback system, outlining library processes and networks, administrators and managers can quickly determine areas for improvement that directly apply to the library's goals and missions" Laughlin and Wilson (2020). Idiegbeyan-Ose and Esse (2013, p. 65) reiterated the need for user feedback when they stated that "user feedback is considered as a more reliable factor in measuring the utility and effectiveness of any library". In the words of Kiriri (2018, p. 22), "the success of a library in achieving its target in terms of vision and mission is closely linked to how its users perceive the services offered as well as their attitude towards the same".

It is fundamental to note that the degree to which the library services are perceived as having good quality and valuable depends totally on the availability of relevant and current electronic and print resources, modern activities or services, and facilities which in turn, affects users' attitude towards the use of library services. The need to measure users' perception of library service quality and value include justification of library's existence in the $21^{\text {st }}$-century; decision making; attraction of more funds for library use, the satisfaction of users' need amongst others.

Evidence in literatures have shown that university libraries need to review their users' perception of the quality and value of the services offered to $21^{\text {st }}$-century users in order to ensure it continuously meets their information needs and expectations and in turn will enable 
these libraries, identify areas that should be improved upon. Also, Becker, et al (2017) reported that the results of the library quality survey undertaken in 2008 revealed that the services did not meet the desired standards of users thus; the library implemented an action plan to address the issue. This shows that there is a continuous need of university libraries to assess the level of undergraduates' perception of library service quality provided and its value in this $21^{\text {st }}$-century of technological advancement, as they are exposed to numerous ways of accessing information, such as Google and other electronic media, which in this $21^{\text {st }}$-century has become popular.

\section{Prof. Festus Aghagbo Nwako Library (PFANL), Nnamdi Azikiwe University Awka-case study}

The university library in Nnamdi Azikiwe University Awka which was named after the first Vice-chancellor of the university, Prof Festus Aghagbo Nwako as noted by Onwuka (2010) was first established in 1982 as Awka Campus Library of the defunct Anambra State University of Technology (ASUTECH) which had its headquarters at Enugu. Following the merger between ASUTECH and IMT (Institute of Management and Technology, Enugu) in 1986 the Awka Campus Library was closed down and merged with Enugu Campus Library. The Awka Campus Library was reestablished in 1987 when Awka Campus of ASUTECH was reopened. It later became the University Library of Nnamdi Azikiwe University in 1992 when Awka Campus of ASUTECH became Nnamdi Azikiwe University. The library as further revealed by Onwuka (2010) offers all the services rendered by academic libraries. The departments are organized along the line of functions of the library. The acquisitions' department carries out collections development activities in liaison with the various faculties. It also solicits for gifts and exchanges, bequests, and so on. The cataloguing and classification department processes the acquired materials for use. The circulation department makes the processed materials available for use in the Library or for loans. The reference department attends to users' reference needs. It answers reference queries using available material resources and also offers user advisory services. The serials department provides serials and so on. The bindery repairs damaged materials and also prepare bound volumes of serials. The digital library provides on and offline access to information. It provides a modern and superior alternative to the traditional library methods. The vision of the library may be summarized as follows: to rank among the world's best academic libraries; to employ the best practices in librarianship and Information Technology to provide the necessary support to teaching and research in the university; and to achieve discipline, self-reliance and excellence in the conduct of its affairs.

\section{Research Questions}

The following research questions were formulated to guide the study;

$R Q 1$. What are the library services available at Prof. Festus Aghagbo Nwako Library (PFANL)?

$R Q 2$. What are the available libraries services used by undergraduate students at PFANL?

$R Q 3$. What are undergraduates' perceptions of the quality of library services offered to them at PFANL?

$R Q 4$. What is the perception of undergraduates on the value of library services offered to them at PFANL? 
RQ5. What are the impediments affecting undergraduates' perception of library services quality and value of at PFANL?

\section{Null Hypotheses}

The following null hypotheses were tested at 0.05 level of significance;

Hol. There is no significant difference in the mean rating of male and female undergraduates' perception of the quality of library services offered to them at PFANL.

Ho2. There is no significant difference in the mean rating of male and female undergraduates' perception of the value of library services offered to them at PFANL.

\section{Literature Review}

Available Library Services in universities

One main objective a university library is established is to render services to members of its parent institution through the provision of information resources and services that support learning, teaching, and research. The philosophy of librarianship as opined by Adeoye and Popoola (2011) is based on the rendering of effective library services as well as the provision of relevant resources to users. The university libraries are normally evaluated on the basis of their significant benefaction to the successful achievements of the parent institutions (Dewey, 2014). "As vital parts of their host institutions, university libraries have over the years expanded their range of services to match institutional goals and objectives and have in recent years endeavored to demonstrate their values to the respective user communities" (Egberongbe, 2018, p. 1). Brown and Malenfant (2015) opined that the quality of a university is measured by the services provided by the library because of its unique position in the overall system.

Library service as noted by Maria (2019, p. 4) "comprises all packages of activities which the library renders to the users in order to enhance and achieve the goals of the parent institution". The nature and efficiency of services provided as pointed out by Bamidele, et al. (2012) vary between libraries, while in Nigerian university libraries, research on the provision of library services is no more a new study. Igwe and Onah (2013), in attempt to categorize the services of libraries and information centers grouped them into "technical services (such as collection development, cataloguing, classification, etc.) and readers' services, which are those services that have a direct impact on the users for the satisfaction of their information needs". Nkamnebe, et al (2017, p. 51) looking at library services in general perspective noted that the services often offered in academic libraries involves: "lending services, reference services, reprographic services, referral services, Current Awareness Services, Selective Dissemination of Information, indexing and abstracting services, document delivery, electronic mail services, bibliographic services, user education/orientation services, online searching amongst others". Similarly, Kumar (2008); and Echezona, and Edoka (2009) identified the following available services in libraries to include: "lending services, bibliography instruction, library orientation, general and specific information provision, literature search, readers' advisory service, selective dissemination of information (SDI), bibliographies compilation, indexing and abstracting services, reprographic services, and translation service among others as services that are provided by a university library". 
Madukoma (2015, p. 4) "identified the following services to library registered users: loan services, reference services (both digital and print), interlibrary cooperation services, photocopy services, bibliographical services, binding services, lamination services, printing services, internet services, CD-ROM search, and readers' advisory services, and so on". Different scholars have carried out studies on library services rendered in academic libraries. Bamidele, et al (2012) studied faculty members' expectations of university library services in three universities in Ogun State, Nigeria, and found out that "electronic information resources services, internet services, and circulation services were fully provided and utilized by the respondents, while CD ROM services, online public access catalogue (OPAC), user education, selective dissemination of information (SDI) and current awareness were moderately provided. It was also found that reprographic service, abstracting and indexing, and literature search services were the least provided".

In another dimension, Onuoha (2010) also examined university library services at Babcock University in Nigeria and found that reference, circulation service; binding services, and photocopy were more effectively available, while interlibrary loan services, indexing, and compilation of bibliographies were not effectively available, as attested by respondents. Similarly, Umunnakwe and Onyebinama (2007) studied Imo State University library services in Nigeria and found that the most important services majorly available were circulation, cataloguing, abstracting, reference, and indexing services while interlibrary and information services are moderately available.

\section{Library Services Quality (LSQ)}

Many definitions of service quality abound from multiple perspectives. In all, service quality revolves around recognition and satisfaction of user needs. This shows that meeting users' expectation is of utmost importance. This is why service quality (SQ) is a vital concern. Service quality according to Lumen (2020) refers to users' comparison of service expectations as it relates to the organization's performance. Notably, Allison (2020) opined that SQ measures how well services are delivered, compared to users expectations; and when expectations are met, high-quality services is achieved. Partap (2019, p. 2) defined service quality as "the degree of excellence towards the resources and services provided to the users, and similarly, the users can get the maximum satisfaction and feel delighted". In a nutshell, Patil and Sawan (2018) defined SQ as those services that satisfy users' expectations and perceptions. According to Sayareh and Golfakhrabadi (2016), SQ means to comply with users' expectations on regular basis. Thakuria $(2007, \mathrm{p} .1)$ opined that "quality services means resources and services, which satisfy users' expectations and perceptions". Sahu (2006, p. 235) defined service quality as the "difference between users' expectations and perceptions of service performance and the reality of the service". LQS focus on meeting to a certain degree, the standard required to satisfy users' information needs.

"SQ is an important factor of successful services as it fosters the creation of a positive image and references while strengthening satisfaction" (Benazic, 2012, p. 62); and service competitiveness is decided by quality services (IEEE, 2015). This corresponds with the words of ITU in the Library and Information Science BD Network (2016) that "the collective effect of service performances determines the degree of users "satisfaction". Rave and Giraldo (2014) suggested that SQ allows organizations (library) to achieve better performance in 
regards to value offered to users. Hence, libraries must provide quality services to retain their users and enhance their role (Patil and Sawan, 2018). SCONUL (2020) stated that "good quality library services attract and retain academic high flyers and contribute to the prestige of an institution". Library and Information Science BD Network (2016) identified three characteristics of good services as quality control, quality assurance and quality management.

Qualtrics (2020) stated that service quality is a qualitative measurement and not quantitative. However, in measuring library service quality, many scholars have proposed different models which Moses et al (2016, p. 18) listed as; "WebQUAL, SiteQUAL, E-ServQUAL, DigiQUAL, LibQUAL, Service QUAL". While Wolff-Eisenberg (2019) added LibSat and MISO. However, this study focuses on library quality service and value. To this end, Adam (2017) argued that library SQ model is one of the "tools libraries use to solicit, track, understand and act" upon users' opinions of the quality of services offered. Thakura (2007) listed the tools library management uses to improve their services in a bid to offer better quality services to include, TQM, SERVQUAL and LIBQUAL. Idiegbeyan-Ose and Esse (2013) added Survey as a tool used to assess library quality service and user satisfaction. They further suggested that "competent services are another expectation among library users". Becker, Hartle and Mhlauli (2017, p.12) asserted that "LIBQUAL is based on a survey which contains questions on service provision, information control and the library as a place while SERVQUAL is to determine the quality of the services provided by libraries".

Bansal and Kumar developed a measurement scale of SQ in 2011, as presented by Muyengwa and Marowa (2014) as: "Q=P-E, Where $\mathrm{Q}=\mathrm{Quality}, \mathrm{P}=$ Users' Perception and $\mathrm{E}=$ Expectations" of Services. Qualtrics $(2020$, p. 4) identified five important dimensions of service quality ranked by users as:

a. "Tangibles": physical facilities, personnel and communications

b. "Reliability": the ability to perform accurately the promised services

c. "Responsiveness": willingness to provide prompt services and help users.

d. "Assurance": knowledge of users and ability to display confidence in service delivery.

e. "Empathy": the attention provided to users.

Looking critically at the dimensions above, it is right to say that they are used to measure the interval between library users' high expectations and their perceived real services provided to them. That is, when the dimensions are appropriately used, librarians would understand users' expectations, their perception of library services and areas improvement is needed. In addition, LIBQUAL (2015) identified three dimensions of SQ to include: effect of service, information control and place of library. Lumen (2020) identified steps of providing quality service as identify regular users, assign staff to the users, develop a relationship with the users', get feedback on their experiences and collaborate with them for better services that meet their needs. Service Future (2020, p. 3) asserted that "a strong service climate leads to service quality and to create a good climate and deliver services, three components are needed". They are service strategy (decision on the service parameters, build and design service value and platform), Service performance (training, rewards and empowerment of staff for high service delivery) and users' results (measuring results through feedback from users). 
Some criteria's or benchmark that can be used to measure LSQ as mentioned by Adamu (2017, p. 2) include "currency and relevancy of the information resources, usefulness of catalogues and finding tools in providing access to its collections, ability and cooperation of the library staff to use the facilities to bring information resources and services to the attention of the users and attitude of staff'. Library and Information Science BD Network (2016) identified criteria for quality control to include: topicality, reliability, precision and relevance of information, completeness, flexibility and speed. Idiegbeyan-Ose and Esse (2013, p. 64) opined that "the quality of the resources may be judged from an overall perception as to whether the library can provide access to materials when and where needed". According to Becker, Hartle and Mhlauli (2017) LIBQUAL + Survey and re-running the survey would enable the library to determine progress on issues previously marked as requiring improvement.

Hernonon, et al. in Nyantakyi-Baah (2016) presented service quality in academic libraries into three: information resources, environment for service delivery and services provided by staff. Becker, Hartle and Mhlauli (2017) reported that the results of the LIBQUAL survey undertaken in 2008 revealed that the services did not meet the desired standards of users thus; the library implemented an action plan to address the issue. The actions this library took to resolve this were re-organizing the library's information resources and training staff in service delivery. Nyantakyi-Baah (2016, p. 36) asserted that "evaluating library service quality and its relevance will enable libraries to improve upon existing systems to remain attractive to users". In this regards, the users' perception is an important outcome of the evaluation process (Sayareh and Golfakhrabadi, 2016). This is why; Kiran (2010) noted that, when library service is perceived as quality, the services will continually be used, as users' depend on librarians for their information needs. In this light, IEEE (2015) concluded that perception of SQ by users depends basically on the service provision through staff activities among others. LSQ is a continuous process and assessment should be done regularly for feedback (Muyengwa and Marowa, 2014). For example, SMU libraries organize a broad survey in which their library users are given the opportunity to assess different services and use the outcome to enhance existing services. According to Kulkarni and Deshpande (2012, p. 3), "libraries need to have a system for regular interaction with users". Furthermore, for knowledge of users' expectations, it is important to establish interaction channels and frequent dialogue with users. This indicates that librarians' participation of users in the assessment of their service, would increase their usage of library services, as they are important assets and stakeholders. Santa Clara University Library (2019) expressed that the assessment of LSQ helps the staff understand and act on users' opinion about the library SQ.

\section{Value of Library Services (VOLS)}

Values according to Online Oxford Dictionary on Lexico.com (2020, p. 1), are "principles or standards of behavior; one's judgment of what is important". Similarly, The Network (2020) defines value as the quality (positive or negative) that renders something desirable. However, value for library services is users' judgment of the importance, usefulness, or worth of library services. Tetteh and Nyantakyi-Baah (2019) pointed that user satisfaction indicates the value of the library, and they defined library value as "the degree at which users are pleased with the library services, staff attitude and library environment in the fulfillment of their needs and expectations". Emerald (2020, p. 22) stated that "value-in-use is similar to VOLS, as it tries to 
determine the value of a particular service to a user, using in-depth interviews". IdiegbeyanOse, Nkiki, and Osinulu (2017, p. 2), stated that "the issue of value-added services defines the continuous relevance of the libraries in conferring prestige and expanding the frontiers of scholarship in their respective parent institutions". The value of academic library services especially university libraries to their patrons has generated a crucial issue in the $21^{\text {st }}$-century library management, to effectively serve library users, bring back the potential users, protect the prestige and boost the image of the library. This supports the claim of the American Library Association (2020, p. 1), that the "foundation of modern library rests on an essential set of core values that define, inform and guide librarians". In this technological era, libraries globally are devising the best ways to add value to services offered to $21^{\text {st }}$-century users', in a bid to invite more users' and continue to be relevant in the information sector.

In these present times of Information and Communication Technologies advancement that leads to information explosion, libraries are expected to account for the value of their services, as users have many choices of information services, for university libraries to continue to be relevant, not only in the present times but also in the future. Edwards, Rauseo, and Unger (2013, p. 2) asserted that 'users' appreciate the importance and value of library services, but in an increasingly digital world, the roles of libraries are undervalued and occasionally under fire". Public Library Association (2015) opined that librarian' needs to articulate the value of their library services beyond traditional metrics and align with the business world, where profit is measured. According to Ajaiah and Kumah (2011), the library uses technologies and social network sites for their services embedded value inputs to their users and competitive advantage to libraries. Chen, $\mathrm{Chu}$, and $\mathrm{Xu}$ (2012) added that social network sites are innovative and effective ways of offering value-added services to users in the $21^{\text {st }}$-century.

Graves, et al (2018), opined that libraries should continually communicate their value to users and renew outreach services to attract new users and introduce new users. Thomas (2010) concluded that there is a need for our organizational goals to be reinterpreted, in order to reflect contemporary needs and values. Users' value for library services influences their behavior and attitude towards library users. According to Brown (2011, p. 48) "demonstrating library value is of critical importance to all libraries, both to protect services and to serve patrons effectively".

Noh and Choi (2018) grouped the value of library services into three. They are economic value, social value, and educational value. However, this study focuses on educational value. Idiegbeyan-Ose, Nkiki and Osinulu (2017, p. 7) identified areas where a $21^{\text {st }}$-century library can add value in their services as: "value-added library personnel, value collections, valueadded processing of materials and value-added dissemination of information". Tenopir (2012) presented ways to measure the value of library services into three. Namely "Implicit value" (assess the value through evaluation of usage. Thus, "this approach assumes that when the library is used, it has value to users"), "Explicit value" (The focus here is impact and satisfaction of the library users. This approach uses qualitative interview method to ask users the value derived from the use of library services) and "Derived value" (This focus on cost benefits, referred to as Return on Investment). Many librarians have built on the different 
approaches presented by Tenopir. However, the explicit value approach has gained more popularity, as many researchers developed techniques for assessing library services value. This is confirmed in Infor Media Services (IMS) (2020), that value of libraries focused on the "impact of the library on users, based on user perception of the library compared to other alternatives". Oakleaf (2010) devised a formula to measure the value of services as:

Library Value $(\mathrm{LV})=$ Perceived Benefits/Perceived Costs

Infor Media Services (IMS) (2020) presented the measurement of library value as:

$$
\begin{aligned}
& \text { ROI-Library Value }=\text { Perceived Benefits/ Perceived Costs } \\
& \text { Products-Value= Quantity of Products x Price Per Unit of Products. }
\end{aligned}
$$

American Society of Mechanical Engineers (ASME) (2020) opined that users' may perceive the value of library services differently; students may find value in the library environment space and physical structure while lecturers may find value in the depth and breadth of library resources. Skelton (2017) identified ways university libraries can demonstrate their value to students: communicating the library's contributions, quantify library's impact on users' success, enhanced teaching and learning, and match library assessment to the mission of the institution. Brown (2011) asserted that some ways to determine what services users value, want and like are through surveys, focus groups, informal methods, and data collection.

Fig. 1: Conceptual Framework for Perception of Library Service Quality and Value (LSQAV

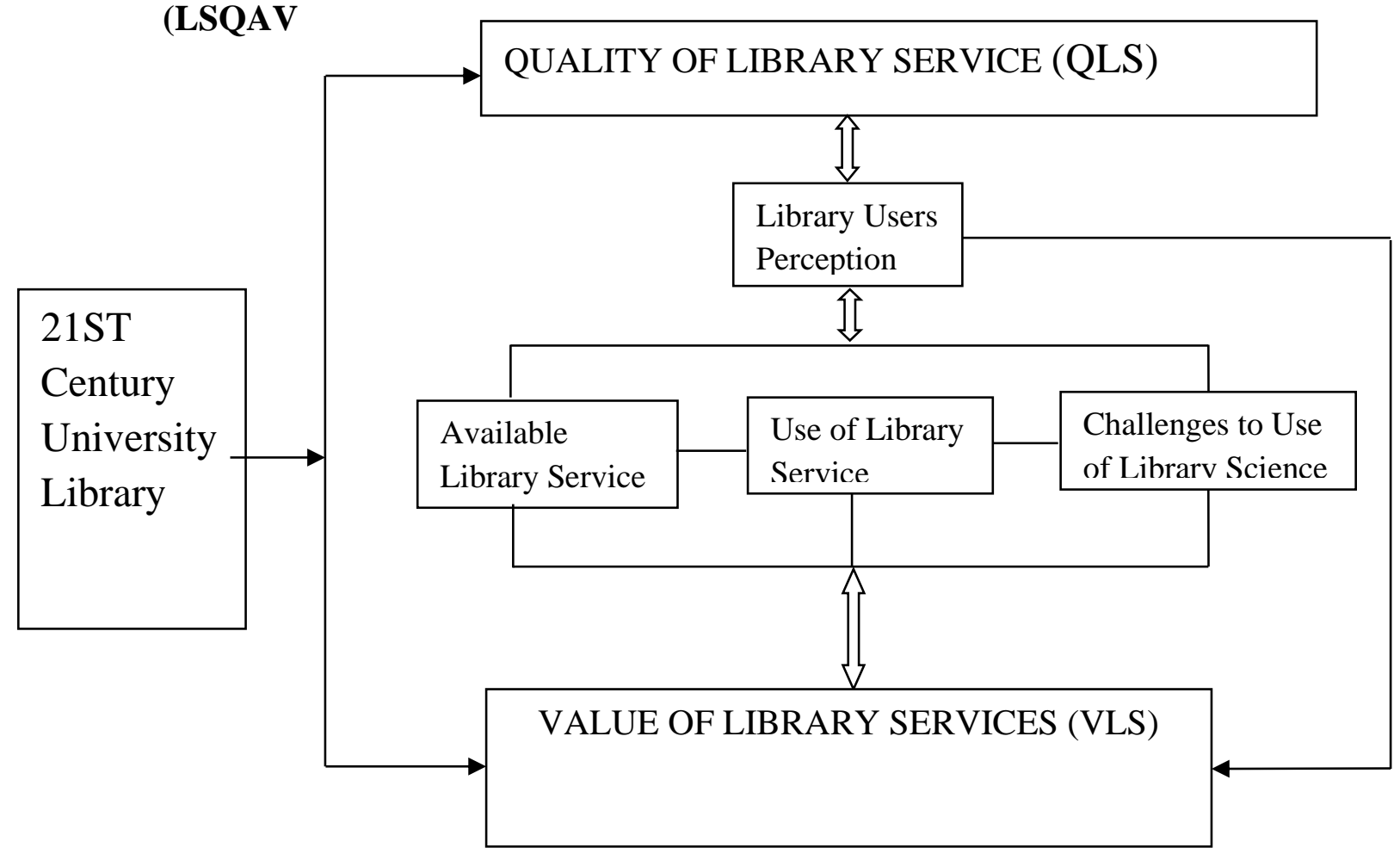

Udem, Ikenwe and Ugwuamoke (2020) 
Figure 1 illustrates the existing relationship of variables in this study. The conceptual framework of this study proposes that in the $21^{\text {st }}$-century university library, two major factors influence users (undergraduates) perception and use of library services. The two factors are Quality Library Services (QLS) and Value of Library Services (VLS). These two factors are however determined by the Available Library Services (ALS) to meet users' high expectations in this $21^{\text {st }}$-century. This further determines users' use, continuous use, and satisfaction of the library services. In other words, if the available services meet users' expectations, they would patronize the library to use their information resources, services, or facilities. But, if it does not meet their expectations, they would be disappointed and this in turn leads to negative perceived quality and value of the library services. Also, the impediments they encounter in the use of the library's services go a long way to influence their perception and satisfaction of library services.

\section{Theoretical Frameworks}

Fig. 2: Theoretical Frame work for Value of library services

This study adopts the framework of Oakleaf (2010) on a research review of the value of academic libraries. Below is the diagrammatical representation of the framework.

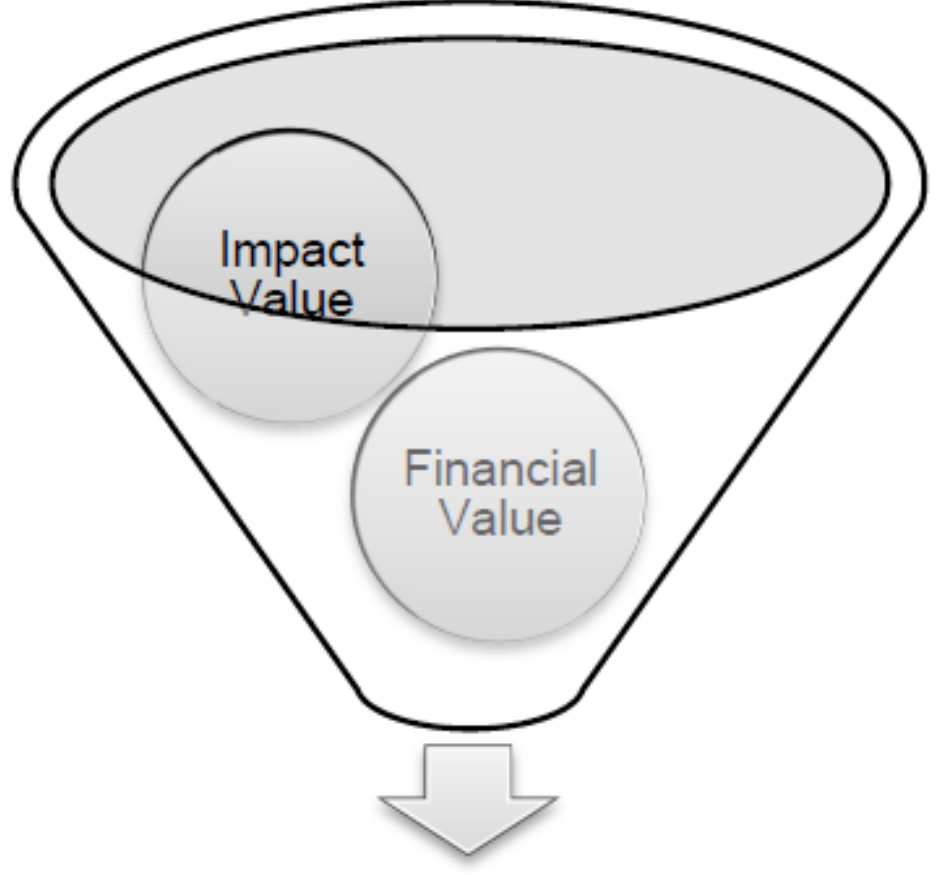

Adopted from Oakleaf (2010, p.23)

The framework by Oakleaf identified two major factors on value for academic library services. The two major factors are; 'impact' and 'financial value'. The financial value is important as an institution that neglects the financial state of its library cannot achieve its goals and survive. On the other hand, academic libraries must judiciously use the financial resources to offer valuable services and support its institution by using other measures to get finance. The 2nd value "Impact" which is most crucial to library users', focuses on the significant contribution of the services to learning, research, and other academic activities. This makes "impact value" more meaningful to academic library users. 
Notably, these values of academic library services are connected to service delivery, as the library is service-oriented. This indicates how important library service delivery is to users'. According to the Oakleaf framework, "service delivery supported by librarian expertise is an important library value; librarian expertise alone is not a sufficient demonstration of library value, librarians must manifest excellent service that results in a value to users". In other words, librarians have a crucial role to play in this as it is expedient for them to display a high level of expertise. Interestingly, the impact has an effect on users' behavior and attitudes towards the use of library services. International Organization for Standardization (2014:14) grouped the impact of library's value into three general aspects to include: "impact of the library on the user; the impact of the library on the parent institution or communication and social impact". However, this study x rayed the impact of university library on the users' (undergraduates).

Fig. 3: Theoretical Framework of Expectation Confirmation Theory for Usage of Library and Information Resources (ECTULIR) Adopted for Perception of Library Quality Services and Value

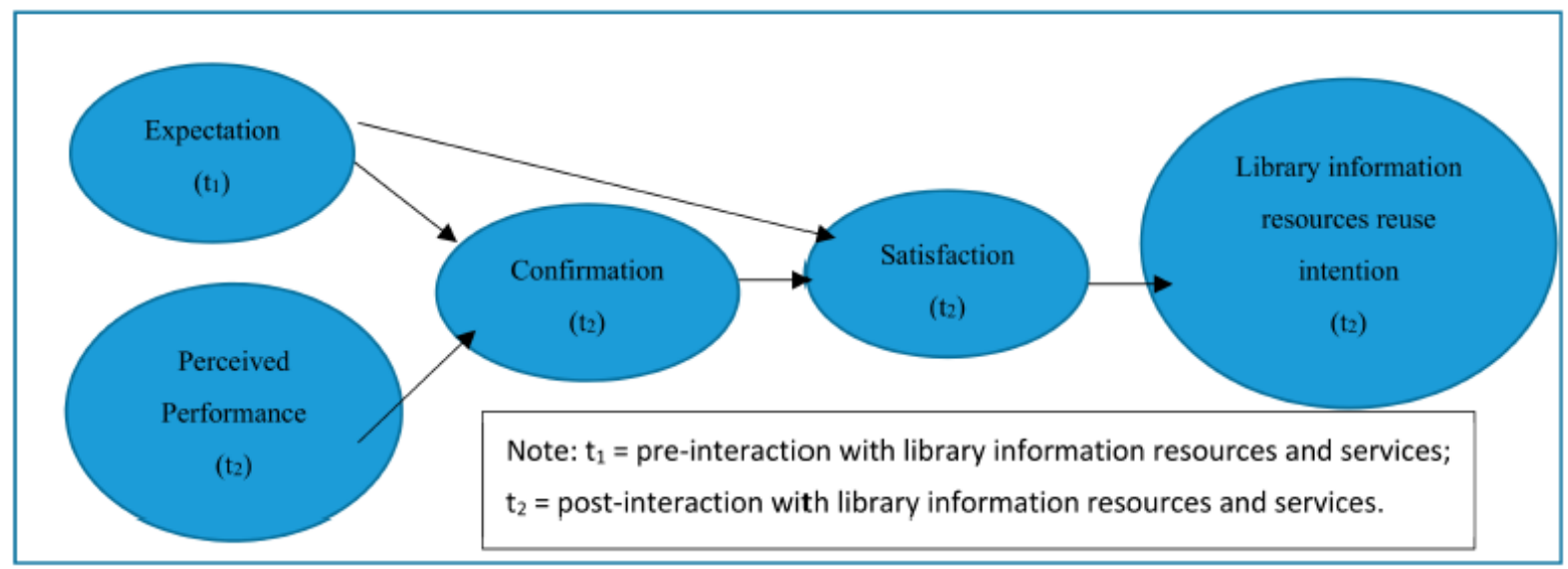

Adopted from Salubi, Ondari-Okemwa and Nekhwevha (2018, p.4)

The framework of expectation confirmation theory for the usage of library and information resources developed in 2018 by Salubi, Ondari-Okemwa, and Nekhwevha, was adopted for this study. The framework was born after a series of interactions with users, particularly undergraduates, perceived opinion of information resources, and services in libraries. An assessment was done by the proponents based on users' initial expectations. Hence, they concluded that if library resources and services meet users' preconceived expectations, there will be increased post-usage satisfaction of the library's information resources and services. This brings positive confirmation. But when the output is different from users' expectations, it becomes negative, which decreases their use and satisfaction. This affects their perceived quality and value of library services. The proponents, therefore, found a significant relationship between the information resources and services provided by libraries to affect undergraduates' perception and satisfaction of library service quality and value. Thus, they concluded that this leads to a decrease in their patronage due to perceived dissatisfaction with their expectations. 


\section{Research Method}

A descriptive survey research design was adopted for the study. According to Nworgu (2015), a descriptive survey is a study which aims at collecting data on and describing in a systematic manner, the characteristics, features, or facts about a given population. Such a study is only interested in describing certain variables in relation to the population. This design was considered appropriate for the study because; it collected data and described in a systematic manner undergraduates' perception of library service quality and value in the $21^{\text {st }}$ century, and only a proportion of the population was studied and findings from this were generalized to the entire population. Prof. Festus Aghagbo Nwako Library (PFANL) in Nnamdi Azikiwe University library was used as a case study. The population of the study consists of 14,196 registered undergraduates of PFANL. The sample size for the study was 120 regular undergraduate library users selected through the accidental sampling technique. In accidental sampling, as pointed out by Nworgu (2015), only elements that the researcher can reach are included. The study employed the use of two instruments which include: observation checklist, use to ascertain the available library services, and a questionnaire used to elicit users' perception of library service quality and value. The instruments were face validated by two experts, one from the Measurement and Evaluation department, and the other one from the Library and Information science department. The internal consistency of instrument on library services used by the undergraduates was established using KudderRichardson which yielded 0.86 while Cronbach's alpha coefficient was used for perceived quality and value of library services which yielded 0.78 and 0.81 respectively. The questionnaires were distributed to the students who came to use the library within the two weeks of the study. In order to avoid one student answering the same questionnaire more than once, they were told not to answer the questionnaire if they have done that before. From 120 questionnaires distributed, 103 copies received were valid, 17 responses are either incomplete or not answered, and so, the efficient rate was 85.8 percent. Data were analyzed using frequency count, percentages, mean and standard deviation, done using SPSS; t-test was used to test hypotheses. The criterion mean scale was used to indicate the mean score. The mean score below 2.50 was rejected (Disagreed/Negative) while the mean score above 2.50 was accepted (Agreed/Positive).

\section{Presentation and Analysis of Data}

\section{Demographic Data}

Table 1: Gender of Respondents

\begin{tabular}{|l|l|l|}
\hline Gender & Frequency & Percent \\
\hline Male & 45 & 43.7 \\
\hline Female & 58 & 56.3 \\
\hline Total & 103 & 100 \\
\hline
\end{tabular}

Table 1 show that the females, represented by (no: $58,56.3 \%$ ) were more than the male represented by (no: 45, 43.7\%). 
Figure 1: Gender of Respondents

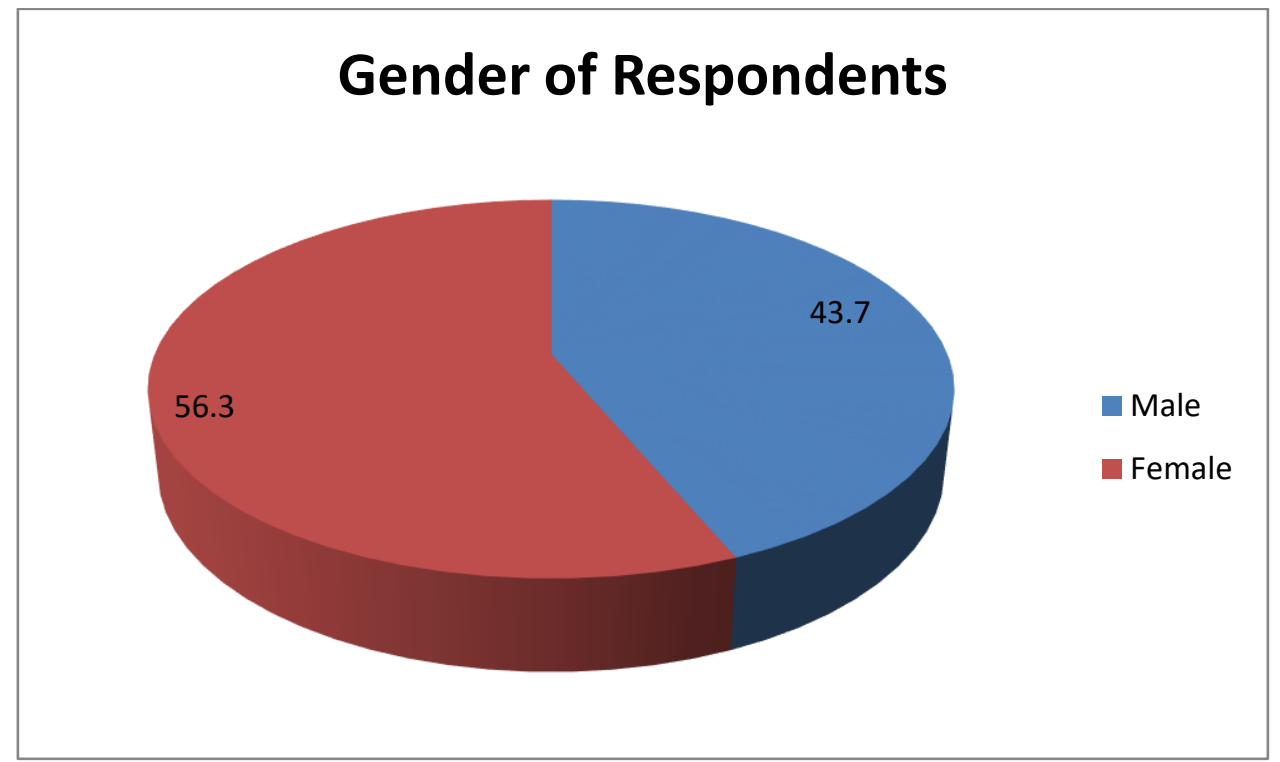

Results in Figure 1 shows that, out of the 103 respondents, (n: 58, 56.3\%) are female while (n: 45, 43.7\%) are male.

\section{Research Question 1}

What are the library services available at Prof. Festus Aghagbo Nwako Library (PFANL)?

Table 2: Respondents' ratings on library services available at Prof. Festus Aghagbo Nwako Library (PFANL)

\begin{tabular}{|c|c|c|c|}
\hline $\mathbf{S} / \mathbf{n}$ & Items & Available & Not Available \\
\hline 1. & Reference service & $\sqrt{ }$ & \\
\hline 2. & Users orientation services & $\sqrt{ }$ & \\
\hline 3. & Computer/Internet services & $\sqrt{ }$ & \\
\hline 4. & Reprographic services & $\sqrt{ }$ & \\
\hline 5. & Loan services & $\sqrt{ }$ & \\
\hline 6. & Bibliographic control services & & - \\
\hline 7. & Assistance/ support services & $\sqrt{ }$ & \\
\hline 8. & Serial services & $\sqrt{ }$ & \\
\hline 9. & Bindery services & $\sqrt{ }$ & \\
\hline 10. & Disability support services & & - \\
\hline 11. & $\begin{array}{l}\text { Cataloguing and classification } \\
\text { services }\end{array}$ & $\sqrt{ }$ & \\
\hline 12. & Circulation services & $\sqrt{ }$ & \\
\hline 13. & $\begin{array}{l}\text { User registration and clearance } \\
\text { services }\end{array}$ & $\sqrt{ }$ & \\
\hline 14. & Current awareness services & $\sqrt{ }$ & \\
\hline
\end{tabular}




\begin{tabular}{|l|l|c|c|}
\hline 15. & Book reserve services & & - \\
\hline 16. & Recreation services & & - \\
\hline 17. & Research support services & $\sqrt{ }$ & \\
\hline 18. & Open and closed access services & $\sqrt{ }$ & \\
\hline 19. & $\begin{array}{l}\text { Preservation and conservation } \\
\text { services }\end{array}$ & $\sqrt{ }$ & \\
\hline $\mathbf{2 0}$ & Interlibrary loan services & & - \\
\hline
\end{tabular}

Table 2 shows the available library services and those not available in PFANL. From the list of services, the researchers observed through a checklist that the following services were available- reference services, users' orientation services, computer/internet services, reprographic services, loan services, assistance/support services, serial services, bindery services, cataloguing, and classification services, circulation services, user registration and clearance services, current awareness services, research support services, open and closed access services. On the other hand, the following services were not available; bibliographic control services, disability support services, book reserve services and recreation services.

Research Question 2: What are the available libraries services used by undergraduate students at PFANL?

Table 3: Respondents' ratings on available library services used in PFANL

\begin{tabular}{|l|l|l|l|l|l|}
\hline S/n & Items & $\begin{array}{l}\text { Freq. of } \\
\text { Yes }\end{array}$ & $\begin{array}{l}\text { \% of } \\
\text { Yes }\end{array}$ & $\begin{array}{l}\text { Freq. of } \\
\text { No }\end{array}$ & $\begin{array}{l}\text { \% of } \\
\text { No }\end{array}$ \\
\hline $\mathbf{1 .}$ & Reference service & 67 & 65.0 & 36 & 35.0 \\
\hline $\mathbf{2 .}$ & Users orientation services & 51 & 49.5 & 52 & 50.5 \\
\hline $\mathbf{3 .}$ & Computer/internet services & 56 & 54.4 & 47 & 45.6 \\
\hline $\mathbf{4 .}$ & Reprographic services & 41 & 39.8 & 62 & 60.2 \\
\hline $\mathbf{5 .}$ & Loan services & 59 & 57.3 & 44 & 42.7 \\
\hline $\mathbf{6 .}$ & Bibliographic services & 68 & 66.0 & 35 & 34.0 \\
\hline $\mathbf{7 .}$ & Staff assistance services & 57 & 55.3 & 46 & 44.7 \\
\hline $\mathbf{8 .}$ & Serial services & 73 & 70.9 & 30 & 29.1 \\
\hline $\mathbf{9 .}$ & Bindery services & 58 & 56.3 & 45 & 43.7 \\
\hline $\mathbf{1 0 .}$ & Disability support services & 15 & 14.6 & 88 & 85.4 \\
\hline $\mathbf{1 1 .}$ & Catalogue and classification services & 83 & 80.6 & 20 & 19.4 \\
\hline $\mathbf{1 2 .}$ & Circulation services & 80 & 77.7 & 23 & 22.3 \\
\hline $\mathbf{1 3 .}$ & Users registration & 90 & 87.4 & 13 & 12.6 \\
\hline $\mathbf{1 4 .}$ & Current awareness services & 47 & 45.6 & 56 & 54.4 \\
\hline $\mathbf{1 5 .}$ & Book reserve services & 54 & 52.4 & 49 & 47.6 \\
\hline $\mathbf{1 6 .}$ & Recreation services & 20 & 19.4 & 83 & 80.6 \\
\hline $\mathbf{1 7 .}$ & Research assistance services & 56 & 54.4 & 47 & 45.6 \\
\hline $\mathbf{1 8 .}$ & Open and closed access services & 59 & 57.3 & 44 & 42.7 \\
\hline $\mathbf{1 9}$. & Preservation and conservation services & 54 & 52.4 & 49 & 47.6 \\
\hline $\mathbf{2 0}$ & Interlibrary loan services & 17 & 16.5 & 86 & 83.5 \\
\hline
\end{tabular}


Table 3 shows that serial, catalogue, circulation, and users' registration in the library had the highest percentages, which indicates that they are highly used. Bibliographic and reference services are moderately used while computer/internet services, loan services, staff assistance services, bindery services, book reserve, open and closed access service, preservation, and conservation are moderately used. On the other hand, Reprographic and Current awareness services are fairly used.

Research Question 3: What are undergraduates' perceptions of the quality of library services at PFANL?

Table 4: Respondents' mean scores on their perception on the quality of library services offered at PFANL

\begin{tabular}{|l|l|l|l|l|}
\hline $\begin{array}{l}\text { S/ } \\
n\end{array}$ & \multicolumn{1}{|c|}{ ITEMS } & X & SD & Decision \\
\hline 1. & $\begin{array}{l}\text { Provision of serial Services in the Library is of good } \\
\text { quality }\end{array}$ & 3.32 & 0.79 & Agree \\
\hline 2. & $\begin{array}{l}\text { Computer/ Internet Services provided in the Library is } \\
\text { Satisfactory }\end{array}$ & 2.27 & 1.12 & Disagree \\
\hline 3. & $\begin{array}{l}\text { Circulation Services Provided in the Library is of good } \\
\text { quality and Excellent }\end{array}$ & 2.53 & 0.89 & Agree \\
\hline 4. & $\begin{array}{l}\text { Reference Services Provision in the Library is of high } \\
\text { quality and Commendable to use }\end{array}$ & 2.95 & 0.87 & Agree \\
\hline 5. & $\begin{array}{l}\text { The Assistance Services Provided by the Library } \\
\text { Personnel to users is Encouraging and good quality }\end{array}$ & 2.82 & 0.89 & Agree \\
\hline 6. & $\begin{array}{l}\text { Reprographic services Provided in the Library is } \\
\text { Satisfactory }\end{array}$ & 2.44 & 0.85 & Disagree \\
\hline 7. & $\begin{array}{l}\text { The Provision of User Orientation Services in the } \\
\text { Library is of standard and Commendable }\end{array}$ & 2.56 & 1.24 & Agree \\
\hline & Grand Mean & 2.51 & Agree \\
\hline
\end{tabular}

Table 4 reveals that the respondents perceived provision of serial services (3.32), circulation services (2.53), reference services(2.95), assistance by library personnel (2.82), and user orientation services (2.56) as of high/good quality, commendable and encouraging while respondents attest that computer/internet services (2.27) and reprographic services (2.44) provided in the library are not satisfactory in this 21 st century. In other words, the respondents' perception of these two service quality is low. The grand mean of the items in table three (3) is 2.51. From the criterion mean scale indicated which states that mean score below 2.50 will be rejected while a mean score above 2.50 will be accepted as high, the grand mean score of 2.51 is above 2.50 , which shows that the respondents have an overall positive perception of the quality of library services offered to them. 
Research Question 4: What is the perception of undergraduates on the value of library services offered at PFANL?

Table 5: Respondents' mean scores on their perception of the value of library service offered at PFANL

\begin{tabular}{|c|c|c|c|c|}
\hline S/n & ITEMS & $\overline{\mathrm{X}}$ & SD & Decision \\
\hline 1. & $\begin{array}{l}\text { Provision of serial services in the Library is valuable and } \\
\text { Satisfactory }\end{array}$ & 3.31 & 0.75 & Agree \\
\hline 2. & $\begin{array}{l}\text { Computer/ Internet Services provided in the Library is } \\
\text { Satisfactory and commendable }\end{array}$ & 2.17 & 1.04 & $\begin{array}{l}\text { Dis } \\
\text { agree }\end{array}$ \\
\hline 3. & $\begin{array}{l}\text { Circulation Services Provided in the Library is valuable } \\
\text { and useful. }\end{array}$ & 2.51 & 0.87 & Agree \\
\hline 4. & $\begin{array}{l}\text { Reference Services Provision in the Library is valuable, } \\
\text { useful and Commendable for use }\end{array}$ & 2.84 & 0.84 & Agree \\
\hline 5. & $\begin{array}{l}\text { The Assistance / Supportive Services Provided by } \\
\text { Library Personnel are Encouraging, valuable and useful. }\end{array}$ & 3.07 & 0.42 & Agree \\
\hline 6. & $\begin{array}{l}\text { Reprographic services Provided in the Library is } \\
\text { Satisfactory encouraging and commendable }\end{array}$ & 2.34 & 0.81 & Disagree \\
\hline 7. & $\begin{array}{l}\text { The Provision of User Orientation Services in the Library } \\
\text { is Commendable and satisfactory }\end{array}$ & 2.44 & 0.88 & Disagree \\
\hline & Grand Mean & 2.67 & & \\
\hline
\end{tabular}

Table 5 indicates that the respondents' perceived provision of serial service (3.31), circulation services (2.51), reference services (2.84), and assistance/ supportive services by library personnel (3.07) as valuable and more commendable. While respondents attest that computer/internet services (2.17), reprographic services, and user orientation services provision were not satisfactory, commendable, and encouraging. The grand mean of the items in table four (4) is 2.67. From the criterion mean scale indicated which states that mean score below 2.50 will be rejected while a mean score above 2.50 will be accepted as high, the grand mean score of 2.67 is above 2.50 , which shows that the respondents have a positive perception of the library services offered to them.

Research Question 5: What are the impediments affecting undergraduates' perception of library services quality and value of at PFANL.

Table 6: Respondents' ratings on the impediments affecting undergraduates' perception library services quality and value at PFANL

\begin{tabular}{|c|l|c|c|c|}
\hline $\mathrm{S} / \mathrm{n}$ & \multicolumn{1}{|c|}{ Items } & $\mathrm{X}$ & $\mathrm{SD}$ & Decision \\
\hline 1. & Insufficient current information resources & 3.19 & 0.95 & Agree \\
\hline 2. & Unfriendly attitude of library staff & 2.99 & 1.01 & Agree \\
\hline
\end{tabular}




\begin{tabular}{|c|l|c|c|c|}
\hline 3. & Slow internet connectivity service & 3.32 & 0.94 & Agree \\
\hline 4. & $\begin{array}{l}\text { Insufficient user Orientation / formal training } \\
\text { programs }\end{array}$ & 3.23 & 0.96 & Agree \\
\hline 5. & $\begin{array}{l}\text { Limited access and insufficient availability of } \\
\text { modern facilities }\end{array}$ & 2.97 & 1.06 & Agree \\
\hline 6. & Insufficient training on technology use & 2.66 & 1.18 & Agree \\
\hline 7. & Unsteady Power Supply & 2.51 & 0.87 & Agree \\
\hline
\end{tabular}

Table 6 reveals that the impediments affecting undergraduates perception of high-quality library services and value in this 21 st century in PFANL are insufficient current information resources (3.19), an unfriendly attitude of the staff (2.99), slow internet connectivity (3.32), limited access, and insufficient availability of modern facilities $(2,97)$, insufficient training on technology use (2.66) and unsteady power supply (2.51). This means that the listed impediments above affect a high positive perception of library services quality and value in PFANL. The standard deviation scores ranging from $0.94-1.32$ mean that the respondents' mean scores were closely related.

Null Hypothesis 1: There is no significant difference in the mean rating of male and female undergraduates' perception of the quality of library services at PFANL.

Table 7: Summary of t-test Analysis on difference in the Mean Rating of Male and Female Undergraduates' Perception of the Quality of Library Services in PFANL

\begin{tabular}{|l|l|l|l|l|l|l|l|l|}
\hline Undergraduates & $\mathrm{N}$ & Mean & $\begin{array}{l}\text { Std. } \\
\text { Deviation }\end{array}$ & $\mathrm{T}$ & $\mathrm{A}$ & $\mathrm{df}$ & P-value & Remark \\
\cline { 1 - 7 } & 45 & 19.07 & 4.40 & .34 & .05 & 101 & .74 & Accept \\
\hline Female & 58 & 18.78 & 4.35 & & \\
\hline
\end{tabular}

Table 7 shows that the calculated t-value of .34 has a P-value of .74 which is greater than the 0.05 significance level $(\mathrm{t}=.34, \mathrm{p}>0.05)$. Therefore, the null hypothesis that states, there is no significant difference in the mean rating of male and female undergraduates' perception of the quality of library services in PFANL is accepted. This indicates there is no significant difference between male and female undergraduates' perception of the quality of library services.

Null Hypothesis 2: There is no significant difference in the mean rating of male and female undergraduates' perception of the value of library services in PFANL.

Table 8: Summary of t-test Analysis on difference in the Mean Rating of Male and Female Undergraduates' Perception of the Value of Library Services in PFANL

\begin{tabular}{|l|l|l|l|l|l|l|l|l|}
\hline Undergraduates & $\mathrm{N}$ & Mean & $\begin{array}{l}\text { Std. } \\
\text { Deviation }\end{array}$ & $\mathrm{T}$ & $\mathrm{A}$ & $\mathrm{Df}$ & P-value & Remark \\
\hline Male & 45 & 20.07 & 8.29 & 1.93 & .05 & 101 & .06 & Accept \\
\hline Female & 58 & 17.64 & 4.27 & & & \\
\hline
\end{tabular}


Table 8 shows that the calculated t-value of 1.93 has a $\mathrm{P}$-value of 0.06 which is greater than the 0.05 significance level $(t=1.93, p>0.05)$. Therefore, the null hypothesis that there is no significant difference in the mean rating of male and female undergraduates' perception of the value of library services in PFANL is accepted.

\section{Discussion of Findings}

Findings revealed in Table I that the female undergraduates, represented by $56.3 \%$ were more than the male undergraduates represented by $43.7 \%$. This may be assumed that in Prof. Festus Aghagbo Nwako Library (PFANL) in Nnamdi Azikiwe University Awka, female undergraduates visit the library more than the males. This contradicts the finding of Daramola (2013) who found that males' undergraduates visit the library more than females, although they both have the same purpose of using library services, different usage. Danbabale (2015) opined that both males and females in the university system maximize library services.

The available library services at PFANL are reference services, users' orientation services, computer/internet services, reprographic services, loan services, assistance/support services, serial services, bindery services, cataloguing and classification services, circulation services, user registration, and clearance services, current awareness services, research support services, open and closed access services. This collaborates the study of Madukoma (2015), who identified the following services to library registered users: "loan services, reference services (both digital and print), interlibrary cooperation services, photocopy services, bibliographical services, binding services, lamination services, printing services, internet services, CD-ROM search, and readers' advisory services, and so on".

The finding revealed that serial, catalogue, circulation, and users' registration in the library had the highest percentages, which indicates that they are highly used. Bibliographic and reference services are moderately used while computer/internet services, loan services, staff assistance services, bindery services, book reserve, open and closed access service, preservation, and conservation are moderately used while reprographic and Current awareness services are fairly used. This is at variance with the findings of Nyantakyi-Baah (2016), who found that photocopying, lending, printing, and scanning had the highest use while bibliographic instruction and orientation had the lowest use. Also at variance is the findings of Tetteh and Nyantakyi-Baah (2019), who found photocopying services as the highest valued and satisfied services, followed by lending services.

Findings show a positive perception of the quality of library services offered to undergraduate users' of PFANL, as revealed in Table III, that the services are of high/good quality, commendable and encouraging. This finding is in agreement with Adamu (2017), who found the perception of undergraduates towards the use of services highly satisfactorily and appreciable. Kiriri (2018) found out that to a large extent, the library service quality was perceived as positive which directly affects how the library was used. However, the study found undergraduates has low perception of the service quality of computer/ internet services and reprographic services, as they disagree that the services are not satisfactory and commendable. This shows that these two services should immensely be improved upon in this 21st century. This agrees with the finding of Ahmed and Islam (2012), who found students low perception of internet services and printing services, hence they were not satisfied with 
these services. Finding also corresponds with Idiegbeyan-Ose and Esse (2013) finding that scanning, photocopying, and binding services should be improved upon.

The finding equally shows a high positive value of library services at PFANL. This was indicated as the respondents attest that the provision of serial service, circulation services, reference services, and assistance/ supportive services by library personnel are valuable and more commendable. This is in agreement with the finding of Idiegbeyan-Ose and Esse, who found that the students studied were satisfied to a large extent with their library services and concluded their perception of library service value is high. Finding is in variance with the findings of Noh and Choi (2018), who found librarians value of library services higher than users. In addition, Cheng (2012) found that the values of library services can be judged independently, which requires recognition reflected in the perceived usefulness of the library.

The finding also revealed a host of impediments that affects high library service quality and value in this 21 st century at PFANL to include: insufficient current information resources, an unfriendly attitude of staff, slow internet connectivity, limited access and insufficient availability of modern facilities, insufficient training on technology use and unsteady power supply. This agrees with the finding of Tetteh and Nyantakyi-Baah (2019), who found reasons why some users are dissatisfied with library services offered as slow internet, availability of few computers, poor users' assistance, and insufficient information literacy training. This was confirmed by Peris and Otike in Adamu (2017) that university libraries in the 21st century are faced with the problem of irregular or non- use of resources and services because of their perception of irrelevance, lack of skills, slow internet, inadequate collections, and unhelpful staff. This agrees with the finding of Oluwunmi, Durodola, and Ajayi (2016), that discourteous or unfriendly staff of the library, physical facilities, and no constant electricity affects the perceived quality and value of the library services. Ahmed (2012) also found a lack of new edition of books, slow internet services, and unfriendly library staff behavior affecting students' perceived library-quality services.

The null hypothesis that states that there is no significant difference in the mean rating of male and female undergraduates' perception of the quality and value of library services in PFANL were accepted. This indicates that there is no significant difference between male and female undergraduates' perceived Library service quality and value. This collaborates the result of Danbabale (2015), who found gender difference not significant in library services because both male and females participate in accessing services of the library, thus both genders get higher preferences in certain services, but the difference is not significant. Ahmed (2015) opined that there is no need for gender differences in libraries, both male and female must be given the same priority in library services. This shows that both males and females are involved in maximizing library services.

\section{Conclusion}

This study explored undergraduate library user perception of PFANL service quality and value in the $21^{\text {st }}$-century. The continuous assessment of undergraduates' perception of the university library service quality and value is necessary specifically in this $21^{\text {st }}$-century where library has practically improved their information services delivered to their users by adopting digital technology in information resources and services provision to augment the 
conventional method. Therefore, the study concluded that undergraduates' have a positive perception of the library services quality and value at Prof. Festus Aghagbo Nwako library (PFANL), Nnamdi Azikiwe University Awka. Interestingly the positive perception of these undergraduates of library services in this $21^{\text {st }}$-century has boosted their perceived value or worth of these services, as they have a high positive value of the services. However, low perception of the quality of computer/ internet services and reprographic services by the undergraduates in PFANL implies that these two services should immensely be improved upon in this 21 st century. More so, the study concluded that there is no significant difference between the male and female perception of library service quality and value in PFANL.

\section{Recommendation}

Based on the findings of this study, the following recommendations have been offered to increase undergraduates' perception of library service quality and value in Prof. Festus Aghagbo Nwako library (PFANL), Nnamdi Azikiwe University Awka.

1. Library management at PFANL should sustain undergraduates' level of perceived library quality and value, and boost it by providing continuous, relevant, and current information resources and services especially on the aspect of computer/Internet services and reprographic services suitable in this $21^{\text {st }}$-century.

2. The challenges faced by these users' in PFANL should be addressed by library management and university management.

3. Library management should organize continuous training for all categories of staff on staff/users' relationship to improve immensely their relationship with users and ensure they undergo the training.

4. University management and all stalk holders should improve the financial allocation by providing enough funds to enable the library to meet up with the trend in technology and other aspects of the library activities and imbibe in modern services that will be acceptable in this $21^{\text {st }}$-century of trending technologies.

\section{References}

Adamu, R. (2017), "Assessment of library service quality and user satisfaction among undergraduate students of Yusuf Maitama Sule University (YMSU) library", Library Philosophy and Practice (e-journal), 1675, available at: https://digitalcommons.unl.edu/libphilprac/1675.

Adeoye, M. O. and Popoola, S. O. (2011), "Teaching effectiveness, availability, accessibility and use of library and information resources among teaching staff of schools of nursing in Osun and Oyo State, Nigeria", Library Philosophy and Practice, available at: http//: www.webpages.uidaho.edu/ mbolin/adeoye-popoola.htm.

Ahmed, S. and Islam, R. (2012), "Students' perception on library service quality: A qualitative study of IIUM library", I-managers Journal on Educational Psychology, Vol. 6, No. 2, pp. 19-29, available at: https://academia.edu/264400.

Allison, J. (2020), "Service Quality: Definition and Dimensions", available at: https://study.com/academy//e.

American Society of Mechanical Engineers (ASME), (2020), "Demonstrating the Value of the Library Collections", available at: https://asmedgitalcollection.asme.org. 
Ayiah, E. M. and Kumah, C. H. (2011), "Social networking: a tool to use for effective service delivery to clients by African Libraries", available at: http://conference.ifla.org/pastwlic/2011/183-ayiah-en.pdf

ALA (2020), “Core Values of Librarianship", available at: https://ala.org/advocacy/int.

Ayoung, A. D, Bekoe, S. and Azindow, F. B. (2020), "Research constraints and quality public library service delivery in Ghana", Journal of International Information and Library Review, Vol. 52, No. 1, pp. 10-31, available at: https://tandfonline.com/doi/abs/10.1080/10572317.

Bamidele, I. A., Omeluzor, S. U., Madukoma, E., George, P. N. and Ogbuiyi, S. (2012), “A Comparative Study of Faculty Members' Expectations of Academic Library Services in Three Universities in Ogun State, Nigeria", Canadian Social Science, Vol. 8, No. 4, pp. 202-210. DOI: http://dx.doi.org/10.3968/j.css.1923669720120804.1855.

Becker, D., Hartle, H. and Mhlauli, G. (2017), "Assessment of use and quality of library services, accessibility and facilities by students at Cape Peninsula University of Technology". South African Journal of Library and Information Science”, Vol. 83, No. 1, pp. 11 - 25, available at http://sajlis.journals.ac.za.doi:10.7553/83-1-1642.

Benazic, D. and Dosen, D. O. (2012), "Service Quality Concept and Measurement in the business consulting market", available at: https://researchgate.net/pub/.

Brown, K. and Malenfant, K. J. (2015), “Academic Library Contributions to Student Success: Documented Practices", Association of College and Research Libraries, available at: http://www.ala.org/acrl/sites/ala.org.acrl/files/content/issues/value/contributions_repor t.pdf.

Cheng, P.Y. (2012), "Perceiving usefulness: the perception of users in school libraries and librarians in Hong Kong", available at: https://www.researchoutput.csu.edu.au.

Chen, D.Y., Chu, S. K. and Xu, S. (2012), "How do libraries use social networking sites to interact with users", ASLST 2012, October 28-31, Baltimore, MD, USA, available at: https://www.asis.org/asist2012/proceedings/submission/85.pdf.

Daramola, C. F. (2013), "Gender differences in the use of academic resources: The case of FUTA library”, International Journal of Library and Information Science, Vol.5 No.8, pp. 256-261, available at: https://www.academicjournals.org/IJLIS.

Danbabale, A. (2015), "Gender dimension of use of library: the case of Federal University, Lokoja", Journal of Information and Knowledge Management, Vol. 6, No. 1, available at https://www.ajol.info>view.

Dewey, B. (2014), "Leading the library by leading the campus: a dean's perspective", Library Leadership Management, Vol. 29, No. 1, pp. 1-10, available at: https://journals.tds.org/llm/index.php/llmarticle/view/7099

Echezona, R. I., and Edoka, B. E. (2009), "Information Services Provision by Special Collection Units in Federal and State Nigerian University Libraries", International Journal of Information and Communication Technology, Vol. 6, No. 1, available at: https://www.ajol.info/index.php/ict/article/view/48209.

Edwards, J.B., Rauseo, M.S. and Unger, K. R. (2013), "Community centred: 23 Reasons why your library is the most important place in town", Public Library Online, available at: https://www.publiclibraryonline.org.

Egberongbe, H. S. (2018), "An approach to quality improvement of Nigerian university library services: a framework for effective quality management implementation", Information Development, pp. 1-22. DOI: 10.1177/0266666918811397. 
Emerald (2020), "Assessing the Value of Library Services", available at: Retrieved from https://idgrouppublishing.com.

Fagan, J. C. (2014), "The Dimensions of Library Service Quality: A Confirmatory Factor Analysis of the LibQUAL+ Instrument", Library \& Information Science Research, Vol. 36, No. 1, pp. 36-48. DOI: https://doi.org/10.1016/j.lisr.2013.10.003

Gama, U.G. (2013), "Reference services in the digital age: what hope for reference librarians in Nigeria", Bayero Journal of Library and Information Services, Vol. 1, No. 1, pp. 32-39.

Graves, S., LeMire, S., Mastel, K. and Farrell, S. (2018), "Demonstrating Library Value Through Outreach Goals and Assessment", available at: https://er.educause.edu/article.

Idiegbeyan-Ose, J. and Esse, U. C. (2013), "Students satisfaction with academic library resources and services: the Covenant University library experience", Journal of Information and Knowledge Management: Information Impact, Vol. 4, No. 1, pp.6479, available at: https://eprints.covenantuniversity.edu.ng.

Idiegbeyan-Ose, J., Nkiko, C. and Osinulu, I. (2017), "Value-added service to academic library users in $21^{\text {st }}$ century: using competitive intelligence approach", Library Philosophy and Practice (e-journal). Available at https://digitalcommons.unl.edu/libraryphilosophypractice/1570.

IEEE (2015), "Service Quality and its impact on user satisfaction in Indian University Librar", available at: https://www.ieexplore.iee.org/doc.

Informed Services (IMS) (2020), "Measuring library outcomes and Value", available at: https://blog.stcloudstate.edu/i.

International Organization for Standardization (2014), "Information and documentation: Methods and procedures for assessing the impact of libraries", available at: https://www.iso.org >standard.

Igwe, K. N. and Onah, F. A. (2013), "Issues and concerns in service delivery system of libraries to users in the globalization era", In Issa, A. O., Igwe, K. N. and Uzuegbu, C. P. Provision of library and information services to users in the era of globalization, Lagos, Waltodanny Visual Concept, pp. $20-41$.

Kiran, K. (2010), "Service quality and customer satisfaction in academic libraries: Perspectives from a Malaysian University", Vol. 59, No. 4, Emerald Insight, available at: http//:emerald.com/insight.

Kiriri, P.N. (2018), "Service delivery: the perceptions of users' of library services in a private university in Africa", European Journal of Multidisciplinary Studies, Vol. 3, No. 4, available at: https://www.ejmds.kiriri.pdf.

Kulkarni, M. and Deshpande, N. J. (2012), "Empowering Library Users, Establishing Channel of Communication for Service Quality Expectations of Trainers from Government Administrative Training Institute (ATI) Libraries in India", International Federation of Library Association, available at: https://conference.ifla.org/ifla78.

Kumar, K. (2008), “Library Organization”, India, Publishing House PVT Ltd.

Laughlin, S. and Wilson, R. W. (2020), "The quality lib: a guide to self-improvement, Better efficiency and Happier customers", American Library Association, Available at: https://.ala.org/tools/libraries.

LIBQUALITY (2015), "History of LibQuality", available at: https://www.libqual.org/about/

LIS BD Network (2016), "Service Quality Management in Libraries", available at: https://lisbdnet.com/service-q. 
Lumen, C. (2020), "Service Quality”, available at: https://courses.lumenlearning.com.

Madukoma, E. (2015), "Users' perception of electronic reference services in Babcock University Library, Ilishan-Remo, Ogun State, Nigeria”, IFLA WLIC. Available at: https://www.ifla.org/files/assets/reference-andinformationservices/publications/2015_ifla_reference_section-madukoma-en2.pdf.

Maria, I. E. (2019), "A Pilot Study on Awareness and Use Library Services among Postgraduate Students in Nigeria", Library Philosophy and Practice (e-journal), 2283, available at: https://digitalcommons .unl.edu/libphilprac/2283.

Moses, C. L., Olaleke, O., Akinbode, M. O., Gbenga, A. M., Olokundun, M. and Aka, D. (2016), "Perceived service quality and user satisfaction in library environment", Asian Journal of Information Technology, Vol. 15, No. 1, pp. 18-25, available at: https://eprints.covenantuniversity.edu.ng.

Muyengwa, G. and Marowa, Y. N. (2014), "Evaluation of library service quality at a local university", $6^{\text {th }}$ International Conference on Mechanical, Production and Automobile Engineering, November 27-28, Cape Town, South-Africa, available at:https://psycentre.org>extaimages.

Noh, Y., Lee, K. H and Choi, S. K. (2018), "A study on comparing the perception between librarians and users about libraries value", International Journal of Knowledge Content Development and Technology, Vol. 8, No. 2, available at: https://www.ijkcdt.net.

Nkamnebe, E. C., Egwuatu, C. A. and Nkamnebe, C. B. (2017), "Students' perception of information resources and services in Nigeria Police Academy Library Wudil, Kano State, Nigeria", Library Research Journal, Vol. 2, pp. 50-65.

Nyantakyi-Baah, L. (2016), "User perception of academic library service quality and value: The case of the Ghana Institute of Journalism and Ashesi University College Libraries", Master thesis, University of Cape Town, available at: https://open.uct.ac.za>handle.

Oakleaf, M. (2010), "The value of academic libraries: A comprehensive research, review and report", Association of College and Research Libraries. Available at: https://www.acr/.ala.org/value.

Oluwunmi, A. O., Durodola, O. D. and Ajayi, C. A. (2016), "Students' perceived quality of library facilities and services in Nigerian private universities", Journal of Education and Training Studies, Vol. 4, No. 5, available at: http://dx.doi.org/10.11114/jets.v4:5.1396.

Online Computer Library Centre (OCLC) (2011), "Perceptions of libraries", available at https://www.oclc.org > reports.

Online Oxford Dictionary (2020), "Definition of Value", available at: lexico.com/definition/value.

Onuoha, U. D. (2010), "Faculty assessment of, and satisfaction with, library services in Babcock University, Nigeria", Contemporary Humanities, Vol. 4, No. 1/2, pp. 287297.

Onwuka, E. O. (2010), "Brief on the university library", Nnamdi Azikiwe University Awka.

Patil, S. and Swant, S. (2018), "Service quality expectations of academic library users", National conference on enhancing the role of the library in teaching and learning, Eprints in Library and Information Science, available at: https://.eprints.rclis.org/32356. 
Partap, B. (2019), “A review of service quality assessment of library and information centres", Library Philosophy and Practice (e-journal), 2333, available at: https://digitalcommons.unl.edu/libphilprac/2333.

Public Library Association (2015), "Customers or Patrons? How You Look at Your Library,s users", available at: https://www.publiclibrariesonline.

Qualtrics (2020), "How to Measure Service Quality", available at: https://qualtrics.com.

Rave, J. P. and Giraldo, L. M. (2014), "What Can't Be Ignored in Service Quality Evaluation: Application Contexts, Tools and Factors", available at: https://scielo.org.co/scielo.ph.

Santa Clara University Library (2019), "Library Service Quality Survey (LibQuality+)", available at https://libguides.scu.edu/libq.

Salubi, O. G., Ondari-Okemwa, E. and Nekhwevha, F. (2018), "Utilization of Library Information Resources among Generation Z Students", Facts and Fiction, Vol. 6, No. 2, p. 16, available at: https://doi.org/10.3390/publications6020016.

Sayareh, J. and Golfakhrabadi, N. (2016), "Service quality evaluation and ranking of container terminal operators", The Asian Journal of Shipping and Logistics, Vol. 32, No. 4, pp. 203-212, available at: https://sciencedirect.com.

SCONUL (2020). The Value of Academic Libraries, available at http://sconul.ac.uk/page/.

Service Future (2020), "The Three Components of Excellent Service Quality", available at: https://servicefuture.com.

Skelton, V. (2017), "Academic Library Impact-How to Demonstrate Value", available at: https://infortoday.eu/Articles/.

SMU Libraries (2020), "Library Service Quality Survey", available at: library.smu.edu.sg/about.us/lib-ser-quality-service.

Tenopir, C. (2012), "Beyond usage: measuring library outcomes and value", Library Management, Vol. 33, No. 1\&2, pp. 5-13. DOI:10.1108101435121211203275.

Tetteh, E. O. A. and Nyantakyi-Baah, L. (2019), "Library value through satisfaction: The case of academic libraries in Ghana", International Journal of Library and Information science, Vol. 11, No. 15, pp. 44-57. Available at: https://doi.org/10.5897/IJLIS/2019.0886.

Thakuria, P. K. (2007), "Concept of quality in library services: An overview", available at: https://www.ir.inflibnet,ac.in

Thomas, S. (2010), "Introductory comments developing strong library bugdets: information professionals share best practices", Library Connect Pamphlet, Vol. 12, pp. 1-16, available at: https://libconnect.elsevier.com/sites/default/files/icp121.

The Network (2020), "Definitions for Value", available at: https://definitions.net>value.

Umunnakwe, G. C. and Onyebinama, C. O. (2007), "Academic Library Services in Imo State: the Challenges so Far", An International Journal of Information and Communication Technology, Vol. 4, No. 2, pp. 163-178.

Wolf-Eisenberg, C. (2019), "Landscape of library service quality tools", available at: https://www.sr.ithaka.org/blog/landscape. 